\section{Regards sur l'économie allemande}

Bulletin économique du CIRAC

$69 \mid 2004$

Varia

\title{
Droit social
}

BAUER Jobst-Hubertus, KRIEGER Steffen, Kündigungsrecht Reformen 2004. Gesetz zu Reformen am Arbeitsmarkt und ,Hartz-Gesetze'. Erläuterungen - Synopse - Materialien

\section{(2) OpenEdition}

12 Journals

Édition électronique

URL : http://journals.openedition.org/rea/3463

DOI : 10.4000/rea.3463

ISBN : 978-2-8218-0834-8

ISSN : 1965-0787

Éditeur

CIRAC

Édition imprimée

Date de publication : 1 décembre 2004

ISSN : 1156-8992

\section{Référence électronique}

"Droit social », Regards sur l'économie allemande [En ligne], 69 | décembre 2004, mis en ligne le 27

janvier 2009, consulté le 22 septembre 2020. URL : http://journals.openedition.org/rea/3463 ; DOI https://doi.org/10.4000/rea.3463

Ce document a été généré automatiquement le 22 septembre 2020.

(c) CIRAC 


\section{Droit social}

BAUER Jobst-Hubertus, KRIEGER Steffen, Kündigungsrecht Reformen 2004. Gesetz zu Reformen am Arbeitsmarkt und ,Hartz-Gesetze'. Erläuterungen - Synopse - Materialien

\section{RÉFÉRENCE}

BAUER Jobst-Hubertus, KRIEGER Steffen, Kündigungsrecht Reformen 2004. Gesetz zu Reformen am Arbeitsmarkt und ,Hartz-Gesetze'. Erläuterungen - Synopse Materialien, Verlag Dr. Otto Schmidt, Cologne, 2004, 316 p.

Les réformes de l'Agenda 2010 ont modifié le droit des licenciements, entraînant l'amendement du chapitre III du Code social (SGB III). D'autres lois de réforme du marché du travail sont venues s'y ajouter, connues sous le nom de lois Hartz (voir REA 68/04). Le présent manuel de droit pratique livre une analyse comparée et commentée des anciennes et nouvelles dispositions, augmentée d'exemples pratiques. (ib) 